\title{
Screening and Identification of the Phospholipase D-producing Streptomyces ${ }^{\dagger}$
}

\author{
Tsutomu Yamaguchi, Yoshio Okawa, Kengo Sakaguchi and Naoki Muto \\ Research Laboratory, Toyo Jozo Co., Ltd., Ohito-cho, Shizuoka-ken \\ Received January 18,1973
}

\begin{abstract}
About 2,000 strains of streptomycetes and 200 strains of molds were tested for egg yolkdegrading activity. A strain isolated from soil was found to produce the strong activity in the culture medium.

The egg yolk-degrading substance was found to be phospholipase D and the producing strain was identified as Streptomyces hachijoensis. It was found out that the strains producing egg yolk-degrading substance appeared with high frequency in whirl-forming species in genus Streptomyces.
\end{abstract}

There have been a number of reports on phospholipase $\mathrm{D}$ of plant materials such as carrot and cabbage. ${ }^{2 \sim 3)}$ It has long been thought that phospholipase $\mathrm{D}$ is virtually absent in microorganisms. Recently, however, two bacteria were found to produce the enzyme, that is, Haemophilus parainfluenzae ${ }^{4}$ and Corynebacterium ovis. ${ }^{5}$

In order to obtain microorganisms which are able to produce phospholipases, about two thousand strains of streptomycetes and two hundred strains of molds were examined for the producibility of those enzymes by using egg yolk agar plate for the enzyme assay. A strain isolated from soil excreted a large amount of the egg yolk-degrading substance. Thin-layer chromatographic analysis revealed that the substance produced phosphatidic acid and choline from lecithin.

The present paper deals with the screening for the production of egg yolk-degrading substance, identification of the substance, phospholipase $\mathrm{D}$, and taxonomical identification of a potent culture belonging to Streptomycetes. The relationship between morphological characteristics and producibilities of the egg yolk-degrading substance in Streptomyces are also described.

\footnotetext{
+ Phospholipase D from Microorganisms. Part I. A part of this work was presented at the Annual Meeting of the Agricultural Chemical Society of Japan, Sendai, April 3, 1972.
}

\section{MATERIALS AND METHODS}

Assay of the egg yolk-degrading activity. Egg yolk plates were prepared as follows:

Beat yolk of four eggs (free from white) was suspended in $100 \mathrm{ml}$ of saline and $25 \mathrm{~g}$ of celite were added to the suspension. The mixture was then filtered with Toyo-filter paper No. 2. One part of the filtrate was added to 9 parts of melted $2 \%$ agar solution (at about $60^{\circ} \mathrm{C}$ ). To prevent infection by microorganisms, streptomycin was added to the mixture at the final concentration of $10 \mu \mathrm{g} / \mathrm{ml}$. Ten milliliter portion of the egg yolk agar was poured into a petriđish.

Sample to be tested was absorbed to a pulp disc (diameter: $8 \mathrm{~mm}$ ) which was dried on filter paper at room temperature for about $30 \mathrm{~min}$.

After the disc was put on the egg yolk plate, the plate was incubated at $37^{\circ} \mathrm{C}$ for $15 \mathrm{hr}$ and the diameter of the clear zone (in $\mathrm{mm}$ ) formed around the pulp disc was measured.

Culture. About 2,000 cultures of streptomycetes and 200 cultures of molds were isolated from soils and plants and subjected to examination of the producibilities of egg yolk-degrading substance.

In the case of streptomycetes, a $100 \mathrm{ml}$ aliquot of medium in a $500 \mathrm{ml}$-Erlenmyer flask sterilized at $120^{\circ} \mathrm{C}$ for $20 \mathrm{~min}$ was inoculated with a strain and cultivated at $30^{\circ} \mathrm{C}$ for 4 or 5 days with shaking.

The cultured broth was centrifuged to obtain clear supernatant which was used for assay of the activity. The medium used consisted of polypeptone, $0.75 \%$; meat extract, $0.75 \%$; soluble starch, $1 \% ; \mathrm{NaCl}, 0.3 \%$ and $\mathrm{MgSO}_{4} \cdot 7 \mathrm{H}_{2} \mathrm{O}, 0.1 \%$, pH 7.2 .

In screening tests for molds, the medium consisted of potato extract, $10 \%$; C.S.L., $0.5 \% ; \mathrm{KH}_{2} \mathrm{PO}_{4}, 0.5 \%$; $\mathrm{MgSO}_{4} \cdot 7 \mathrm{H}_{2} \mathrm{O}, 0.25 \%$; $\mathrm{pH} 6.5$. 
Thin-layer chromatography. Thin-layer chromatography (TLC) was carried out on silica gel $G$ with chloroform-methanol-water $(65: 25: 3$, by volume) as the developing solvent. The substances on the TLC were detected by spraying ninhydrin solution or $50 \%$ $\mathrm{H}_{2} \mathrm{SO}_{4}(\mathrm{v} / \mathrm{v}) . \quad R f$ values of authentic phosphatidylethanolamine, phosphatidic acid and ethanolamine were $0.66,0.91$ and 0.11 , respectively.

Enzymes. Phospholipase D from cabbage was purchased from BDH Chemicals Ltd. (Poole, England) and the others from Seikagaku Kogyo Co., Ltd. (Tokyo).

Chemicals. Phosphatidylethanolamine and lecithin were prepared from egg yolk according to the method of Dawson. ${ }^{6)}$ Phosphatidic acid was prepared according to the method of Kates ${ }^{7}$ by hydrolysis of lecithin with phospholipase D of cabbage.

Ethanolamine hydrochloride was purchased from Tokyo Kasei Kogyo Co,, Ltd. (Tokyo). Other chemicals were of the purest grade commercially available.

\section{RESULTS}

1. Screening of strains capable of degrading egg yolk

Among about 2,000 cultures of Streptomyces examined, 4 cultures were found to produce the egg yolk-degrading substance (Table I).

Table I. EgG YolK-Degrading Activities in Stx Cultures of Streptomycetes and Molds

\begin{tabular}{|c|c|c|c|}
\hline \multirow{2}{*}{ Microorganism } & \multirow{2}{*}{$\begin{array}{c}\text { Strain } \\
\text { No. }\end{array}$} & \multicolumn{2}{|c|}{ Activity $(\mathrm{mm} \phi)$} \\
\hline & & 3 day & 5 day \\
\hline Streptomyces sp. & A 853 & 12.8 & 14.0 \\
\hline 11 & A 1025 & 14.3 & 15.6 \\
\hline$"$ & A 1143 & 18.2 & 19.6 \\
\hline " & A 1579 & 16.0 & 16.8 \\
\hline \multicolumn{4}{|l|}{ Mold } \\
\hline unidentified & M 53 & $10.8^{a}$ & $11.7^{a 1}$ \\
\hline$"$ & M 76 & $10.0^{a}$ & $10.5^{a 1}$ \\
\hline
\end{tabular}

a) Cloudy zone

In this Table, Streptomyces sp. A 1143 showed the highest potency of the egg yolkdegrading activity. This strain was isolated from soil collected at Ikeda city, Osaka prefecture.

In the molds, 2 cultures among about 200 cultures showed the egg yolk-degrading activity. However, the activities of both cultures were low. Also some other cultures of molds gave small cloudy zones on the egg yolk plate.

2. Identification of egg yolk-degrading substance

These selected microorganisms have a possibility to produce simultaneously different enzymes, because an egg yolk suspension is claimed to be cleared by protease of Streptomyces (Pronase), phospholipase of snake venom, lipase of Candida, pancreatic lipase and lipoprotein lipase.

In our preliminary experiments, pancreatic lipase, phospholipase A of snake venom, trypsin and some detergents such as SDS, deoxycholate and Triton X-100 made clear zone on the egg yolk plate. But pronase, phospholipase $\mathrm{C}$ of Clostridium, lipases of Candida and Rhizopus showed no appreciable reaction on the plate.

Since Streptomyces sp. A 1143 gave the highest enzymatic activity among the selected cultures, it was used in the following investi-



FIG. 1. Thin-layer Chromatography of the Reaction Products of Phosphatidylethanolamine with the Egg Yolk-degrading Substance Produced by Streptomyces sp. A 1143.

Reaction: Broth filtrate $(0.5 \mathrm{ml})$ of Streptomyces sp. A 1143 was added to the mixture of $40 \mathrm{~mm}$ phosphatidylethanolamine $(0.2 \mathrm{ml})$ and $0.05 \mathrm{M}$ Tris- $\mathrm{HCl}$ buffer $(\mathrm{pH} 7.5,0.3 \mathrm{ml})$. The mixture was incubated at $37^{\circ} \mathrm{C}$ for $20 \mathrm{~min}$.

a: Standard phosphatidylethanolamine, b: Reaction products, c: Standard ethanolamine, d: Standard phosphatidic acid.

Solvent system: chloroform-methanol-water (65:25: 3), Plate: silica gel G, Detecting reagent; $50 \%$ sulfuric acid. 
gations for elucidation of the egg yolk-degrading substance.

The broth filtrate of Streptomyces sp. A 1143 was added to the suspension of phosphatidylethanolamine and the mixture was incubated at $37^{\circ} \mathrm{C}$ for $20 \mathrm{~min}$. The reaction products were analysed by thin-layer chromatography.

As shown in Fig. 1, two substances having $R f$ values of 0.11 and 0.91 were newly formed from phosphatidylethanolamine ( $R f: 0.66)$.

On thin-layer chromatogram, these two substances corresponded to ethanolamine and phosphatidic acid.

The egg yolk-degrading substance can also attack lecithin to form phosphatidic acid and choline. From these experiments, the main substance giving egg yolk-degrading activity was considered to be phospholipase D.

3. Effect of nutrient sources on the enzyme production

I) Effect of carbon sources. The effect of several carbon sources on production of the egg yolk-degrading substance was examined.

None of the carbon sources employed stimulated the enzyme production. Glucose, sucrose, maltose and fructose were not suitable for the enzyme production.

2) Effect of nitrogen sources. Table II shows the effect of several organic and inorganic nitrogen sources on production of the egg yolk-degrading substance.

Meat extract, C.S.L. and yeast extract were the most suitable sources for the enzyme production.

3) Effect of phospholipid. Since many microbial enzymes have been reported to be formed inducibly, the effect of phospholipid on the above enzyme production was examined.

The results shown in Fig. 2 indicate that lecithin did not show any significant effect on the production of egg yolk-degrading substance.

Table II. Effect of Nitrogen Sources on Production of Egg Yolk-degrading Substance Produced by Streptomyces sp. A 1143

Nitrogen source was added to a medium containing $1 \%$ soluble starch, $0.05 \% \mathrm{MgSO}_{4} \cdot 7 \mathrm{H}_{2} \mathrm{O}, 0.3 \%$ $\mathrm{KH}_{2} \mathrm{PO}_{4}$ and $0.7 \% \mathrm{Na}_{2} \mathrm{HPO}_{4} \cdot 12 \mathrm{H}_{2} \mathrm{O}$. The strain was inoculated in $100 \mathrm{ml}$ medium in a $500 \mathrm{ml}-$ Erlenmyer flask and incubated at $30^{\circ} \mathrm{C}$ on rotary shaker.

\begin{tabular}{lcccc}
\hline \multirow{2}{*}{ N. source } & Conc. & \multicolumn{2}{c}{ Activity $(\mathrm{mm} \phi)$} & Growth \\
\cline { 3 - 5 } & $(\%)$ & 3 day & 5 day & \\
\hline Polypeptone & 1,0 & 8.4 & 8.5 & +++ \\
Casamino acid & 0,5 & 8.4 & 8.5 & +++ \\
Yeast ext. & 1,0 & - & - & ++ \\
Meat ext. & 0,5 & - & - & ++ \\
& 1,0 & 13.2 & 14.3 & +++ \\
Soy bean meal & 0,5 & 14.3 & 15.6 & +++ \\
& 1,0 & 18.8 & 20.5 & +++ \\
CSL & 0,5 & 18.2 & 19.4 & +++ \\
& 1,0 & 12.4 & 13.3 & ++ \\
Asparagine & 0,5 & 10.8 & 11.7 & ++ \\
& 1,0 & 16.0 & 16.8 & ++ \\
Urea & 0,5 & 17.1 & 17.8 & ++ \\
$\left(\mathrm{NH}_{4}\right)_{2} \mathrm{SO}_{4}$ & 1,0 & - & - & + \\
$\mathrm{NaNO}_{3}$ & 0,5 & - & - & + \\
& 0,5 & - & - & + \\
& 0,3 & - & - & + \\
& 0,5 & - & - & + \\
\hline
\end{tabular}






FIG. 2. Effect of Phospholipid on the Production of Egg Yolk-degrading Substance by Streptomyces sp. A 1143.

Lecithin ( $1 \%$ ) was added to the following media. A: soluble starch, $1.0 \%$; meat extract, $0.75 \%$; peptone, $0.75 \% ; \mathrm{NaCl}, 0.3 \% ; \mathrm{MgSO}_{4} \cdot 7 \mathrm{H}_{2} \mathrm{O}, 0.1 \%$; $\mathrm{pH} 7.2$, B: soluble starch, $1.0 \%$; soy bean meal, $2.0 \% ; \mathrm{NaCl}, 0.3 \% ; \mathrm{MgSO}_{4} \cdot 7 \mathrm{H}_{2} \mathrm{O} 0.1 \% ; \mathrm{pH} 7.2$, C: soluble starch, $2.0 \%$; soy bean meal, $0.2 \%$; NaCl, $0.25 \%$; yeast extract, $0.5 \% ; \mathrm{CaCO}_{3}, 0.35 \%$.

Cultural conditions were the same as those in Table II.

- Control; -----. Control + lecithin $(1 \%)$.

4. Taxonomical studies of Streptomyces $s p$. A 1143

Morphological characteristics. Many synthetic and natural media were used for morphological characterization of the strain. Ammonium-Czapek agar which gave good morphological development was used for the microscopic observations.

The morphological characteristics are summerized as follows; (1) Aerial mycelium: Straight to long and bent, primary and secondary whirls, no spirals; $0.8 \sim 1.0 \mu$ in width. (Fig. 3). (2) Conidium: Oval to short cylindrical; $\quad 0.6 \sim 0.8 \times 1.3 \sim 1.5 \mu$ in size; smooth surface under electron microscopy. (Fig. 4). (3) Substrate mycelium: Flexuous to wavy, many branches; $0.6 \sim 0.7 \mu$ in width; no fragmentation and segmentation.

Cultural and physiological characteristics.

The cultural and physiological characteristics of Streptomyces sp. A 1143 are shown in Tables III and IV.

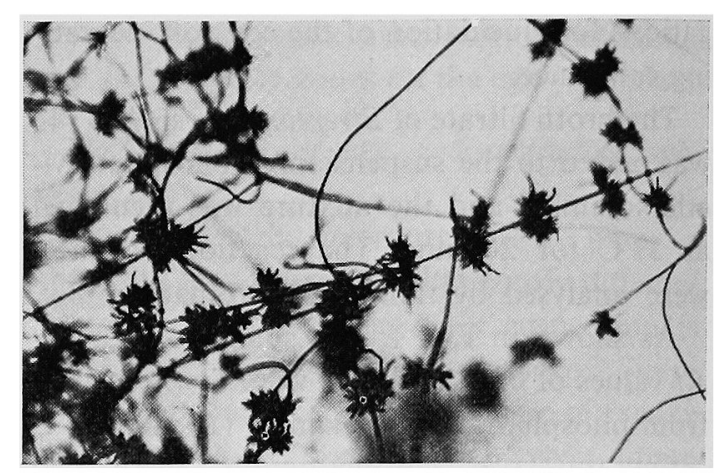

FIG. 3. Aerial Mycelia of Streptomyces sp. A 1143 (photomicrograph).

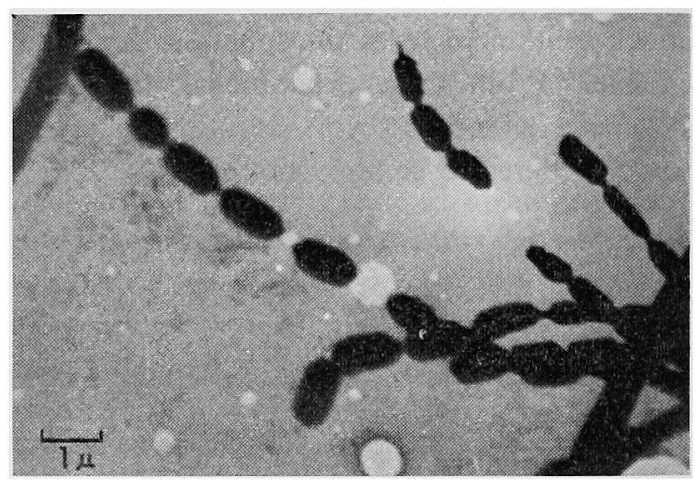

FIG. 4. Conidia of Streptomyces sp. A 1143 (electron micrograph).

From the characters described in these Tables, the strain A 1143 certainly belongs to genus Streptomyces and is assigned to the section Verticillati in "the International Streptomyces Project (ISP) definition." "8 10)

These characters of the strain have some resembrances to those of Streptomyces griseoverticillatus Shinobu et al., ${ }^{111}$ Streptomyces cinnamomeus Benedict et al., ${ }^{12,13)}$ and Streptomyces hachijoensis Yamaguchi. ${ }^{14)}$ By comparison of the taxonomical properties of the strain A 1143 with those of the type cultures of S. griseoverticillatus OEU 722, S. cinnamomeus IFO 12852 and $S$. hachijoensis IFO 12782, it became clear that the strain A 1143 most related to $S$. hachijoensis. Since the strain A 1143 is not clearly differenciated as another species from Streptomyces hachijoensis, the authors conclude that the strain A 1143 belongs to Streptomyces hachijoensis. 
Table III. Cultural Characteristics of Streptomyces sp. A $1143^{a}$,

\begin{tabular}{|c|c|c|c|c|}
\hline Medium & Growth $^{b}$ & Aerial myceliume & $\begin{array}{c}\text { Color of substrate } \\
\text { mycelium }\end{array}$ & $\begin{array}{l}\text { Soluble } \\
\text { pigment }\end{array}$ \\
\hline Czapek agar & Poor, thin & $\begin{array}{l}\text { Poor; Pearl pink ( } 3 \mathrm{ca}) \text { to flesh } \\
\text { pink }(4 \mathrm{ca}) \text { to bisque }(4 \mathrm{ec})\end{array}$ & Colorless & None \\
\hline $\begin{array}{l}\text { Ammonium Czapek } \\
\text { agar }\end{array}$ & Poor, thin & $\begin{array}{l}\text { Poor; Pearl pink ( } 3 \mathrm{ca}) \text { to flesh } \\
\text { pink }(4 \mathrm{ca}) \text { to bisque }(4 \mathrm{ec})\end{array}$ & Colorless & None \\
\hline $\begin{array}{l}\text { Glucose asparagine } \\
\text { agar }\end{array}$ & $\begin{array}{l}\text { Moderate; } \\
\text { intruding into } \\
\text { the medium }\end{array}$ & $\begin{array}{l}\text { Moderate, Cottony; White (a) to } \\
\text { flesh pink (4ca) }\end{array}$ & $\begin{array}{l}\text { Mustard gold ( } 2 \text { pe- } \\
\text { 2ne) to bright } \\
\text { gold }(2 \mathrm{nc}-2 \mathrm{pc})\end{array}$ & None \\
\hline $\begin{array}{l}\text { Glycerol asparagine } \\
\text { agar (ISP No. } 5 \text { ) }\end{array}$ & $\begin{array}{l}\text { Moderate; } \\
\text { intruding into } \\
\text { the medium }\end{array}$ & $\begin{array}{l}\text { Poor; White (a) to light ivory } \\
\text { (2ca) }\end{array}$ & $\begin{array}{l}\text { Light wheat }(2 \mathrm{ca}) \\
\text { to mustard gold } \\
(2 \mathrm{ne})\end{array}$ & None \\
\hline $\begin{array}{l}\text { Starch inorganic } \\
\text { salts agar } \\
\text { (ISP No. 4) }\end{array}$ & Moderate to poor & $\begin{array}{l}\text { Poor; White (a) to pearl pink } \\
\text { (3ca) to light ivory ( } 2 \mathrm{ca})\end{array}$ & $\begin{array}{l}\text { Mustard gold (2ne) } \\
\text { to topaz (3ne) }\end{array}$ & None \\
\hline $\begin{array}{l}\text { Tyrosine agar } \\
\text { (ISP No. 7) }\end{array}$ & $\begin{array}{l}\text { Good; intruding } \\
\text { into the medium }\end{array}$ & $\begin{array}{l}\text { Good to excellent, Cottony, } \\
\text { colorless droplets; Pearl pink } \\
\text { (3ca) to light melon yellow (3ea) } \\
\text { to white (a) }\end{array}$ & $\begin{array}{l}\text { Mustard gold (2pc- } \\
2 \text { pe) }\end{array}$ & None \\
\hline Nutrient agar & Moderate & $\begin{array}{l}\text { Poor; White (a) to light ivory } \\
\text { (2ca) }\end{array}$ & $\begin{array}{l}\text { Mustard gold (2pe) } \\
\text { to amber ( } 3 \mathrm{pe})\end{array}$ & None \\
\hline $\begin{array}{l}\text { Yeast malt ext. } \\
\text { agar (ISP No. 2) }\end{array}$ & $\begin{array}{l}\text { Good; intruding } \\
\text { into the medium }\end{array}$ & $\begin{array}{l}\text { Excellent to good, Cottony, } \\
\text { colorless droplets; Flesh pink } \\
\text { (4ca) to bisque }(4 \mathrm{ec}) \text { to pearl } \\
\text { pink ( } 3 \mathrm{ca})\end{array}$ & Amber $(3 p c-3 n c)$ & None \\
\hline $\begin{array}{l}\text { Oat meal agar } \\
\text { (ISP No. 3) }\end{array}$ & $\begin{array}{l}\text { Moderate; } \\
\text { intruding into } \\
\text { the medium }\end{array}$ & $\begin{array}{l}\text { Moderate, Cottony; Pearl pink } \\
\text { (3ca) to light melon yellow } \\
\text { (3ea) to flesh pink ( } 4 \mathrm{ca})\end{array}$ & $\begin{array}{l}\text { Amber }(3 p c) \text { to } \\
\text { bright gold }(2 p c)\end{array}$ & None \\
\hline $\begin{array}{l}\text { Glucose peptone } \\
\text { gelatine }\end{array}$ & Good & None & Amber (3pc-3pe) & None \\
\hline Skim milk & Good to excellent & None to trace; White (a) & $\begin{array}{l}\text { Gold (2lc) to } \\
\text { squash yellow }(2 \mathrm{ga})\end{array}$ & $\begin{array}{l}\text { None to } \\
\text { amber } \\
(3 \mathrm{nc})\end{array}$ \\
\hline $\begin{array}{l}\text { Peptone yeast iron } \\
\text { agar (ISP No. 6) }\end{array}$ & Good to moderate & None to trace & $\begin{array}{l}\text { Amber }(3 p c) \text { to } \\
\text { topaz (3ne) }\end{array}$ & None \\
\hline
\end{tabular}

Table IV. Physiological Characteristics of Streptomyces sp. A 1143

\begin{tabular}{|c|c|}
\hline Tyrosinase reaction & Negative \\
\hline Nitrite production & Positive, weak \\
\hline Amylase reaction & Positive, weak \\
\hline Gelatinase reaction & Negative \\
\hline \multicolumn{2}{|l|}{ Reaction on milk } \\
\hline Peptonization & Positive \\
\hline Coagulation & Positive, weak \\
\hline Cellulase reaction & Negative \\
\hline \multicolumn{2}{|c|}{ Carbohydrate utilization } \\
\hline Positive & $\begin{array}{l}\text { D-Glucose, Trehalose, } \\
\text { L-Inositol, D-Fructose, } \\
\text { Sucrose }\end{array}$ \\
\hline Negative & $\begin{array}{l}\text { D-Galactose, L-Rhamnose, } \\
\text { Lactose, D-Xylose, } \\
\text { L-Arabinose, Raffinose, } \\
\text { Mannitol }\end{array}$ \\
\hline
\end{tabular}

5. Producibility of egg yolk-degrading substance of whirl-forming Streptomyces

In the morphological studies of four strains of Streptomyces that were selected in the screening test (section 1), it was found out that all these strains, as well as $S$. hachijoensis, belong to whirl-forming Streptomyces. It was assumed that there is some relationship between whirl-forming character and the production of egg yolk-degrading substance. Therefore, the type cultures of whirl-forming Streptomyces were examined on their producibilities of egg yolk-degrading substance.

The results are shown in Table $\mathrm{V}$.

As it was expected, eight out of ten whirlforming species in Streptomyces were found to produce egg yolk-degrading substance. It 
Table V. Producibilities of EgG YolkDEgRADING SUBSTANCE OF VARIOUS WHIRL-FORMING Streptomyces

Medium used was polypeptone, $0.75 \%$, meat extract, $0.75 \%$; soluble starch, $1 \% ; \mathrm{NaCl}, 0.3 \% ; \mathrm{MgSO}_{4}$. $7 \mathrm{H}_{2} \mathrm{O}, 0.1 \%$; 7.2 .

The strain was inoculated in $100 \mathrm{ml}$ medium in a $500 \mathrm{ml}$-Erlenmyer flask and incubated at $30^{\circ} \mathrm{C}$ on rotary shaker.

\begin{tabular}{|c|c|c|c|}
\hline \multirow{2}{*}{ Streptomyces } & \multirow{2}{*}{ Strain No. } & \multicolumn{2}{|c|}{ Activity $(\mathrm{mm} \phi)$} \\
\hline & & 3 day & 5 day \\
\hline S. hachijoensis & A 1143 & 18.2 & 19.6 \\
\hline S. albireticuli & IFO 12737 & 13.6 & 13.7 \\
\hline S. flavopersicus & "I 12769 & 14.1 & 16.2 \\
\hline S. griseocarneus & " 12776 & 14.1 & 16.1 \\
\hline S. mashuensis & " 12888 & - & 9.1 \\
\hline S. mediocidicus & " 13202 & - & 10.0 \\
\hline S. cinnamomeus & " 12852 & 18.2 & 20.0 \\
\hline S. roseoverticillatus & OEU 462 & - & - \\
\hline S. hiroshimensis & 201 & 15.3 & 18.0 \\
\hline S. luteoverticillatus & 486 & - & - \\
\hline
\end{tabular}

can be said that the strains producing egg yolkdegrading substance are found with high frequency in whirl-forming" Streptomyces.

\section{DISCUSSION}

Most reports on phospholipase D have described the enzyme from plant origin. Only a few reports have dealt with the enzyme from microorganisms. The microbial enzymes so far described were obtained from bacteria. Wen-Hsiung Ko et al., ${ }^{15}$ and Bättcher ${ }^{16)}$ demonstrated that some strains belonging to Actinomycetes produced lecithinase-like enzyme. However, the identification of the enzyme was not carried out. Except these report, few investigations have appeared on the formation of phospholipase $\mathrm{D}$ by $A c$ tinomycetes.

Pridham et al., ${ }^{17)}$ reported that the genus Streptomyces was subdivided morphologically into seven sections which were rearranged into four sections by the International Streptomyces Project (ISP) as follows:

Rectiflexibiles which forms straight to flexuous sporophores.

Rectinaculiaperti which forms sporophores as hooks, openloop or greatly extended primitive coils or spirals of wide diameter.

Spirales which forms sporophores as short spore chains with partial spirals; short, gnarled, or compact spirals; extended, long and open spirals.

Verticillati which forms 3 or more sporophores as verticils or whirls spaced regularly on a main hypha.

It is interesting that all of Streptomyces strains producing the egg yolk-degrading substance investigated here belong to the section Verticillati.

Further studies on this series of experiments will be reported in the near future.

Acknowledgement. The authors would like to express their thanks to Prof. R. Shinobu of Osaka University of Liberal Arts and Education for the generous supply of type strains of Streptomyces.

\section{REFERENCES}

1) D. J. Hanahan and I. L. Chaikoff, J. Biol. Chem., 169, 699 (1947).

2) L. Acker, W. Diemair and R. Jäger, Biochem. Z., 322, 471 (1952).

3) M. Kates, Nature, 172, 814 (1953).

4) Y. Ono and D. C. White, J. Bacteriol., 103, 111 (1970).

5) A. Soucěk, C. Michales and A. Součková, Biochim. Biophys. Acta, 144, 180 (1967).

6) R. M. C. Dowson, Biochem. J., 88, 414 (1963).

7) M. Kates, Can. J. Biochem. Physiol., 33, 575 (1955).

8) E. B. Shirling and D. Gottlieb, International Journal of Systematic Bacteriology, 16, 313 (1966).

9) E. B. Shirling and D. Gottlieb, ibid., 18, 69 (1968).

10) T. G. Pridham and D. Gottlieb, J. Bacteriol., 56, 107 (1948).

11) R. Shinobu and Y. Shimada, Botan. Soc. Japan, 75, 170 (1962)

12) R. S. Breed, E. G. D. Murray and N. R. Smith, "Bergey's Manual of Determinative Bacteriology," 7th ed., The Williams and Wilkins Co., Baltimore, 1957, p. 744.

13) S. A. Waksman, "The Actinomycetes," Vol. II, The Williams and Wilkins Co., Baltimore, 1961, p. 195.

14) T. Yamaguchi, J. Antibiot., 7, 10 (1954).

15) W.-H. Ko and F. K. Hora, Soil Science, 110, 355 (1970).

16) K. Bättcher, Microbiologiya, 30, 673 (1961).

17) T. G. Pridham, C. W. Hesseltine and R. G. Benedict, Appl. Microbiol., 6, 52 (1958). 